\title{
SEGMENT PERFORMANCE REPORT SEBAGAI ALAT PENILAIAN PRESTASI MANAJER PUSAT BIAYA (STUDI KASUS PADA UD. GADING JAYA)
}

\author{
Korina Tenau ${ }^{1}$, Jenny Morasa ${ }^{2}$, Rudy J. Pusung ${ }^{3}$ \\ ${ }^{1,2,3}$ Jurusan Akuntansi, Fakultas Ekonomi dan Bisnis, Universitas Sam Ratulangi, Jl. Kampus Bahu, Manado, \\ 95115, Indonesia
}

E-mail : korinatenau662@gmail.com

\begin{abstract}
In the company, needs to implement the division of tasks of each section. In order to determine the extent to which the management of each part has been carrying out the duties and responsibilities of each, hence the need for a method of performance appraisal is segment manager report performance. Segment Performance Report contains information about the grouping of certain costs in accordance with the concept. Purpose o the study was determine whether performance. The research was conducted in UD. Gading Jaya is located at Jl. Kairagi I Manado. Results of this study declare that a performance appraisal manager at UD. Gading Jaya still conventional because it still refers to the production cost report and the statement of income generated by the production department without seeing the direct of income generated by the production department without seeing the direct contribution of the section and according to conventional report.
\end{abstract}

Keywords: Segment Performance Report, Assessment Manager

\section{PENDAHULUAN}

Perusahaan yaitu suatu kegiatan organisasi yang dinyatakan oleh seorang atau sekelompok orang atau badan lainnya yang kegiatan ialah melakukan usaha yang baik didalam produksi barang atau penyediaan jasa. Suatu perusahaan yang didirikan atau dinyatakan dengan tujuan untuk pendapatan laba yang maksimal mungkin dari sejumlah modal yang diikutsertai dalam usaha perusahaan. Keinginan memperoleh laba rugi merupakan karakteristik nyata yang melekat pada perusahaan-perusahaan yang berupa pada persentasi manajer pada umumnya. Perusahaan atau badan usaha yang mempunyai pangsa pasar dan usaha yang cukup luas, banyak melakukan pendelegasian tugas dalam kegiatan organisasi. Dalam mentepkan pengukuran kinerja dan penilaian kinerja, manajemen puncak memiliki serangkain ukuran-ukuran yang menunjukkan strategi perusahaan. Untuk ini yang dapat dilihat sebagai faktor kesuksesan kritis saat ini dan masa depan. Penilaian kinerja yang terhadap perusahaan tersebut bertujuan untuk memotivasi karyawan didalam mencapai sarana organisasi dan dalam memenuhi kebutuhan tersebut yaitu informasi akuntansi bertanggungjawaban (Halim, 2013). Informasi yang dapat dihasilkan yaitu segment performance report, yang yaitu merupakan laporan bertanggungjwab kepada divisi besi hollo yang berisikan pemisahan antara biaya-biaya dapat diterima dan biaya-biaya yang tidak dapat diterima oleh seseorang di dalam posisi organisasinya, sehingga menggambarkan prestasi manajer atau orang yang bersangkutan tersebut. UD. Gading Jaya yaitu suatu perusahaan yang bergerak di bidang manufaktur. Dalam menjalankan kegiatan perusahaan sesuai dengan kegiatan manajer tersebut, perusahaan ini dapat memiliki penghasilan produksi yang berupa produksi besi hollo yang terbaik Indonesi.

UD. Gading Jaya merupakan gambaran yang lebih menjelaskan dari divisi besi hollo bagi manajer pusat biaya untuk dapat melihat prestasi dari manajer yang ada diperusahaan yang dapat digunakan. Untuk mendapatankan biaya-biaya yang dapat dilihat dari manajer perusahaan selama satu priode waktu tertentu yang harus diperhatikkan dengan baik, karena 
dapat memproleh dari hasil penilaian prestasi manajer itu sendiri. Oleh karena itu hal penting maka penilaian persentasi manajer terasa tertarik untuk menganalisis konsep kepada segment performance report sebagai alat penilaian persentasi kinerja manajer sehinga mengambarkan persentasi manajer yang ada di perusahaan tesebut.

\section{TINJAUAN PUSTAKA}

Konsep Akuntansi. Menurut (Pujiyanti, 2015:19) menurut Akuntansi dapat disimpulkan dari dua sudut pandang yaitu definisi dari sudut pandang pemakai jasa akuntansi dan dari sudut pandang proses kegiatannya. Dari sudut pandang pemakai akuntansi dapat dilihat sebagai suatu disiplin ilmu yang menyatakan informasi berupa pelaporan keuangan yang diperlukan oleh pihak-pihak yang berkepentingan mengenai kegiatan ekonomi dan kondisi perusahaan.

Konsep Akuntansi Manajmen yaitu manajemen menurut supriyono (2014:36) akuntansi manajemen ialah penerapan sesuai dengan pereturan tetang manajemen yang ada.

Pengertian Akuntansi Manajemen. Menurut Supriyono (2015: 04), akuntansi manajemen yaitu salah satu kegiatan dari akuntansi manajemen yang bertujuan untuk melihat laporanlaporan suatu kegiatan usaha atau organisasi yang tertentu untuk kepentingan pihak eksternal dan internal dalam rangka pelaksanakan proses kegiatan manajemen yang meliputi perencanaan, membuat keputusan, organisasi dan pengarah serta pengendalian.

Fungsi manajemen. Prowinegoro (2014:05) menyatakan manajamen mempunyai tiga fungsi utama yakni fungsi fungsi akuntansi penuh (Full Accounting Information)fungsi akuntansi penuh dapat mencangkup fungsi masa lalu maupun fungsi yang akan datang. fungsi akuntansi penuh selalu dihubungkan dengan objek fungsi yang dapat berupa satuan usaha, produksi, depertemen atau aktivitas fungsi Akuntansi Diferensial (Differensial Accounting Information) fungsi akuntansi diferensial merupakan taksiran perbedaan aktivatas, pendapatan, atau biaya dalam alternatif tindakan tertentu dibandingkan dengan alternatif tindakan yang lain fungsi akuntansi pertanggungjawaban (responsibility accounting information fungsi akuntansi bertanggungjawab merupakan fungsi aktiva, pendapatan biaya yang digunakan dengan manajer yang bertanggungjawab atas pusat bertanggungjawaban tersebut.

Jenis-jenis manajmen. Prowinegoro (2015:05) membedakan jenis manajemen terbagi atas tiga yaitu Merumuskan keseluruhan strategi dan rencana jangka panjang, merancangkan dan pengendalian baiaya operasional dan memberikan perhatian kepada analisasis menghasilan, biaya, aktivas dan utang mendasarkan segmen performance report, investansi dalam penghasilan lain dalam wilayah pusat bertanggungjawaban, merencanakan dalam mengendalikan biaya operasional dengan memberikan fokus kepada analisis menghasilkan, biaya, aktiva dan utang berdasarkan segmen performance report, investansi dan aspek lain dalam wilayah berteranggungjawab manajemen.

Asas Pengumutan Manajer. Sumarsan (2016:4) mengatakan asas pengumutan manajemen terbagi atas dua yaitu: struktur organisasi pendapatan manajemen, dan proses pengeluaran manajemen.

Syarat pengumutan Manajemen Supriyono (2015:27) berpendapat bahwa ada 6 syarat yang harus dapat diproleh agar pemungutan manajemen berjalan dengan baik yaitu:

1. Merupakan atau harus mendapatkan suatu sistem yang terkordinansi secara terpandu.

2. Proses perencanaan manajemen harus mengikuti suatu sistem yang teratur.

3. Besar dibangun dalam suatu struktur keuangan dimana sumber-sumber yang dapat mengehasilkan dan menyatakan dalam satuan uang.

4. Menyatakan suatu sistem yang seluruh dalam arti merembes kesemua aspek kegiatan perusahaan.

5. Informasi terdiri dari bagian berikutnya. 
6. Berpusat pada program dan pusat bertanggungjawaban.

Sistem Pemungutan Manajemen. Monday dan Noe (2013:104) menemukan bahwa dalam mengenai manajemen terdiri atas 3 sistem pengunaan manajmen yang dapat digunakan, yaitu Work Standard Behaviorally Ancehred ScalesSegment Performance Report. Pengertian Kinerja Manajer Rudianto (2016:310) menyatakan definisi berkeja manajer yaitu "mengumpulkan para manajer untuk mengolah keseluruh bagain sumber daya yang dapat memiliki perusahaan dalam rangka diproleh keseluruhan disumber daya yang dapat di memiliki perusahan dalam rangkai di proleh laba usaha untuk jangka panjang dan jangka pendek.

Manfaat Penilaian Kinerja. Menurut Mulyadi (2013:46) Dilakukan menilai kinerja manajer tertentu memberikan manfaat yang lebih jelas bagi individu yang bersangkutan kemaupun perusahaan. Manfaat penilaian persentasi kinerja manajer yaitu Mengelolah operasi organisasi secara efektif dan efesien melakukan motifasi karyawan secara maksimum; bantu pengambil keputusan yang bersangkutan dengan karyawan; mendapatkan kebutuhan pelatihan perkembangan pegawai dan untuk penyediaan kriteria seleksi dan evaluasi program pelatihan pegawai, menyediakan umpan balik bagi pegawai mengenai bagaimana atasan mereka menilai kinerja mereka; sesuatu dasar bagai pemberian semata.

Penelitian Terdahulu. Yussy Senger (2017), dalam penelitian berjudul tentang Penerapan segment performance Report Sebagai Alat Penilaian Prestasi Manajer dari Divisi besi hollo pada PT. Astral Internasional isinya di Kota Manado. Bertujuan dari penelitian ini adalah untuk dapat mengetahui penilaian segment performance report yang dapat digunakan dalam menilai prestasi manajer divisi besi hollo pada PT. Astral Internasional isinya di Kota Manado. Metode yang digunakan dalam penelitian yaitu Metode Deskriptif. Hasil dari penelitiannya ini menunjukan bahwa menilai prestasi manajer pada PT. Astral Internasional isinya di Kota Manado masih bermanfaat konversional karena masih mengacu pada laba atau rugi yang dihasilkan oleh tanpa melihat kotribusi yang harus didapakai dan digunakan sesuai dengan kemampuan segment performance report.

\section{METODE PENELITIAN}

Jenis Penelitian. Penelitian deskriptif dan kuantitatif yaitu jenis penelitian yang dapat digunakan oleh penelitian ini, dan tujuan untuk menjelas berdasarkan karakteristik nyata dari suatu kelompok ke kelmompok yang laian, maka individu dengan menggunakan angka yang berdasarkan fenomena-fenomena sebagai berikut.

Waktu dan Tempat Penelitian. Bertempat yang menjadi penelitian dari penulis ini yaitu UD. Gading Jaya yang bertempatnya di Jl. Kairagi 1 Kota Manado. Waktu dan Tempat penelitian yang dapat ditentukan oleh pencatat yaitu mulai dari bulan,Februari sampai dengan bulan Maret 2018.

Jenis Data Penelitian. Dalam data kualitatif yaitu data kualitatif yang dapat digunakan dalam penilaian ini mendapkan hasal dari wawancara, sejarah, visi dan misi, serta struktur organisasi kegiatan pada UD. Gading Jaya di Kota Manado Tahun 2017.

Sumber Data Penelitian. Dapat wawancara dan dokumentasi pada UD.Gading Jaya. Khususnya di Daerah Kota Manado merupakan sumber data dari primer yang harus diperlukan dalam penelitian ini.

\section{Metode Pengumpulan Data}

1. Dalam wawancara, Wawancara akan harus dilakukan oleh penelitian dan kepala bagian dari produk Divisi Besi hllo dan pegawai perencanaan dan pengawasan kegiatan perusahaan pada UD. Gading Jaya di Kota Manado.

2. Dalam dokumen. meneliti akan mengumpulkan semua dokumen-dokumen yang berkaitan dengan objek penilain ke pada UD.Gading Jaya di Kota Manado. 
Metode dan Proses Analisis. Mendapatkan metode ini analisis yang dapat digunakan untuk bahas masalah pada penilaian ini yaitu metode analisis deskriptif adalah sesuatu metode yang harus membahas sifat mengurai,atau mengambarkan sesuatu keadaan atau data sertai mengambarkan dangan menyerahkan sesuatu data sedemikian rupa sehingga dapat ditarik kesimpulan untuk menjawab masalah yang ada. Dalam data atau keadaan yang mengambar kedalam penelitian ini yaitu mengenai analisis laporan prestasi manajer sebagai alat penilaian prestasi manajer.

\section{HASIL PENELITIAN DAN PEMBAHASAN}

\subsection{Hasil Penelitian}

Di Kota Manado yaitu salah satu Kota Manado diri Provinsi Sulawesi Utara, Indonesia resmi berdirinya pada Tanggal 13 tahun 2015 perusahaan UD. Gading Jaya yang bergerak di bidang manufaktur Dalam penjelasan fungsinya, manajemen memerlukan informasi berupa laporan atas hasil kegiatan yang telah dicapai oleh setiap divisi dalam organisasinya. Hal ini diperlukan dengan tujuan agar manajemen dapat menilai sampai sejauh mana setiap divisi telah menjalankan tanggungjawabnya sesuai dengan tugas dan wewenang yang didelegasikan. Selain itu laporan tersebut berfungsi sebagai informasi tentang prestasi yang telah dicapai oleh tiap manajer divisi yang bersangkutan, sekaligus sebagai alat motivasi bagi mereka. Dalam hal penilaian prestasi manajer divisi dibutuhkan suatu sarana berupa laporan yang dapat berfungsi sebagai penilaian prestasi manajer divisi yaitu segment performance report. Hal ini selaras dengan konsep dari pada segment performance report yang bisa digambarkan kegiatan manajer divisi dengan lebih baik sebab di dalamnya terdapat pembagian diantara biaya-biaya yang dapat bisa diterima dan biaya-biaya yang tidak dapat diterima untuk manajer divisi. Permasalahan pada skripsi ini menyangkut laporan laba rugi yang telah dihasilkan oleh perusahaan tersebut, apakah sudah dapat menggambarkan prestasi manajer. Dengan demikin untuk pembahasannya, elemen-elemen pengendalian lainnya di dalam perusahaan diasumsikan sudah memadai. Sesuai dengan konsep laporan prestasi yang telah dikemukakan pada bab II sebelumnya, maka di bawah ini akan dibahas mengenai itemitem, yang ada dalam laporan yang dihasilkan oleh perusahaan dihubungkan dengan teori yang ada. Laporan rugi-laba yang dihasilkan oleh divisi secara jelas terlihat pada Tabel 1.

Tabel 1. UD.Gading Jaya Divisi Besi Hollo tahun periode 1 Januari 2017-31 Desember 2017

\begin{tabular}{ll}
\hline Penjualan & $\mathbf{x x x x}$ \\
Haraga pokok penjualan xxxx & $\underline{\mathbf{x x x x}}$ \\
Laba kotor & $\underline{\mathrm{xxxx}}$ \\
Biaya operasional & $\underline{\mathbf{x x x x}}$ \\
Laba/rugi Operasional & $\underline{\mathrm{xxx}}$ \\
Pendapatan (biaya) Non Operasional & $\underline{\mathbf{x x x x}}$ \\
Laba/rugi Terkendali & $\underline{\mathrm{xxxx}}$ \\
Biaya Tak Terkendali & $\underline{\mathbf{x x x x}}$ \\
Laba Rugi Sebelum Pajak & $\underline{\mathbf{x x x x}}$ \\
\hline
\end{tabular}

Sumber : Data Perusahaan Kota Manado 2017 
1. Laba Kotor. Laba kotor merupakan selisih antara penjualan dari produk utama divisi setelah dikurangi dengan harga pokok penjualan. Harga pokok penjualan mencerminkan biaya-biaya yang digunakan sehubungan dengan pembuatan sesuatu produk. Biaya-biaya tersebut terdiri atas:

a. Pemakaian bahan baku;

b. Upah langsung;

c. Biaya pabrik tak langsung yang di dalamnya biaya-biaya seperti: (1) biaya pemakaian bahan baku; (2) upah tak langsung; (3) pemeliharaan mesin pabrik; (4) pemakaian suplai pabrik; (5) listrik; (6) air; dan (7) biaya pabrik lain.

Pada biaya pabrik tak langsung terdapat upah tak langsung di mana di dalam upah ini terdapat gaji dari teknisi asing, yang besar gajinya ditentukan oleh kantor pusat, sedangkan pembebannya dibebankan pada divisi yang bersangkutan. Dengan demikian harga pokok penjualan mencerminkan biaya-biaya yang digunakan untuk pembuatan suatu produk baik yang bersifat variabel, tetap terkendali maupun tidak terkendali bagi divisi yang bersangkutan. Hal ini bila dihubungkan dengan keberadaan dari segment performance report maka laba kotor dari divisi belum memadai untuk digunakan sebagai sarana pengukuran prestasi manajer. Dikatakan demikian karena konsep segment performance report menghendaki adanya laba kotor (kontribusi margin) yang hanya dibebankan dengan biaya pabrik maupun biaya penjualan dan administrasi yang sifatnya variabel karena itu untuk kepentingan penilaian prestasi maka laporan dari divisi khususnya laba kotor perlu diadakan penyesuaian. Penyesuaian dimaksudkan untuk membebankan harga pokok penjualan yang hanya bersifat variabel dalam menghasilkan kontribusi margin. Oleh sebab itu harga pokok penjualan dari divisi hanya berisikan: pemakaian bahan baku, pemakaian bahan pembantu, upah langsung, pemeliharaan mesin pabrik, pemakaian suplai pabrik, listrik, air, biaya pabrik lain yang bersifatnya variabel, dan biaya-biaya penjualan dan administrasi yang variabel.

2. Laba/(Rugi) Terkendali. Laba (Rugi) terkendali merupakan selisih antara laba kotor dengan biaya operasional dan biaya non operasional, setelah memperhitungkan dengan pendapatan yang bersifatnya non operasional. Biaya-baiya operasional adalah sebagai berikut: gaji direksi, gaji karyawan kantor, pemakaian suplai kantor, pemeliharan kendaraan kantor, pemeliharaan gedung kantor, listrik, telpon, air, biaya operasional lain. Sedangkan biaya-biaya yang sifatnya non operasional terdiri atas: jenis pihak ketiga, biaya bunga bank, biaya administrasi bank, dan biaya non operasional lain. Berdasarkan uraian di atas, maka rugi-laba terkendali divisi dibebankan dengan biaya-biaya yang sifatnya variabel tetap diproleh dan yang tidak diproleh bagi divisi yang dapat bersangkutan dengan biaya tidak terkendali yang dimaksud adalah gaji direksi dan jasa pihak ketiga. Hal ini disebabkan karena biaya-biaya tersebut ditentukan oleh kantor pusat yang secara otomatis besarnya biaya tidak bisa dirubah oleh manajer divisi. Dengan demikian, adanya biaya yang sifatnya variabel dalam memperhitungkan laba-rugi terkendali bilamana dikaitkan dengan pengukuran prestasi manajer divisi, keadaan ini di katakan karena contribution controllable by segment manager hanya merupaka kontribusi atas biaya-biaya dapat berbentuk variabel dan biaya bersifat tetap yang diterima oleh manajer yang bersangkutan. Karena itu dengan makasudnya dengan biaya- biaya yang dapat bermanfat tidak dapat diterima dari bagian divisi, contoh pendapatan direksi, jasa pada pihak ketiga penyebab serendahnya contribution controllable by segment manager. Bagaimana halaman ini yang dapat diperlu dan diperhatikan dengan baik dalam pengukuran informasi mengenai pencapaian prestasi manager divisi, dan juga akan mengakibatkan berkurang dari dorongan terhadap manager divisi kedalam rangkai mencapai impian perusahaan. Oleh sebab itu agar untuk melakukan pengukuran prestasi manajer, maka laporan dari manajer divisi sehubungan dengan keberadaan dari laba-rugi 
terkendali yang perlu diadakan penyesuaian-penyesuaian yang dimaksudkan, yaitu dengan hanya membebankan biaya yang dapat berbentuk variabel tetap maupun variabel tetap yang tidak dapat dilakukan oleh karena itu keputusan manajer divisi. Dengan demikian laporan manager dari divisi yang menyangkut kontribusi margin dikurangi bagaian biaya-biaya yang harus dapat diterima dan biaya-biaya tidak dapat terima oleh manager dari divisi besi hollo seperti: gaji karyawan kantor, pemeliharaan kendaraan kantor, pemeliharaan gedung kantor, listrik, air, dan biaya pabrik dan non operasional yang bersifat tetap.

3. Laba/(Rugi) Sebelum Pajak. Laba/(Rugi) sebelum pajak adalah selisih antara laba-rugi terkendali dengan memperhitungkan biaya tak terkendali. Biaya-biaya tak terkendali tersebut adalah: Biaya penyusutan, dan Biaya sewa gedung. Untuk memperjelas pengertian dari masing-masing dan biaya tak terkendali di atas akan dijabarkan sebagai berikut:

a. Biaya Penyusutan. Biaya penyusutan merupakan biaya penyusutan aktiva tetap yang digunakan oleh divisi. Biaya ini dikatakan sebagai biaya tak terkendali karena divisi tidak diperkenankan untuk memperoleh aktiva tetap selain aktiva tetap yang diberikan oleh kantor pusat. Akan tetapi biaya-biaya mempertahankan masa manfaat dari aktiva tetap yang bersangkutan sepenuhnya ditanggung oleh divisi yang menggunakan aktiva tetap tesebut.

b. Biaya sewa gedung. Biaya sewa gedung merupakan biaya sewa yang dikeluarkan oleh divisi atas penggunaan gedung pabrik dan gedung kantor. Besarnya biaya gedung ditentukan oleh kantor pusat di mana divisi tidak mempunyai wewenang untuk memilih alternatif lain atas penggunaan gedung pabrik dan gedung kantor selain menyewa dari pihak lain. Bilamana ditinjau dari sifat biaya tidak terkendali di atas, dapat dikatakan klasifikasi yang dilakukan memadai karena besar kecilnya biaya tersebut tidak dapat dipengaruhi oleh keputusan yang diambil oleh manajer divisi. Keberadaan ini seleras dengan esensi dari pada biaya, sebagai akibat dari keputusan manajer yang mempunyai peringkat lebih tinggi dalam struktur organisasi. Akan tetapi biaya tak terkendali yang ada dalam perusahaan bukan hanya biaya sewa gedung dan biaya penyusutan. Hal ini disebabkan karena biaya-biaya yang memenuhi esensi dari biaya tak terkendali dan oleh divisi belum diklasifikasikan. Sebab itu dengan tidak diklasifikasikannya kedua jenis biaya ini ke dalam biaya tak terkendali akan dapat dipengaruhi performance pada laporan prestasi yang didapatkan dari divisi terlebih khusus menemukan bagaian informasi dari biaya tak terkendali.Kiranya agar pelaporan bertanggungjawab prestasi dari divisi dapat memperlihatkan percakapan manajer divisi besi hollo yang sesunguhnya untuk dapat mengambarkan kegiatan mengunakan biaya yang tidak dapat diterima oleh divisi besi hollo yang bersangkutan, maka di dalam biaya tidak terkendali selain ada biaya sewa gedung dan biaya penyusutan juga harus ada biaya-biaya seperti gaji direksi, upah tak langsung yang menyangkut upah dari teknisi asing dan jasa pihak ketiga.

Dalam mempertahankan memperhatikan pertanggungjawaban di atas dapat dikatakan bahwa melaporankan prestasi manajer yang didapatkan oleh divisi besi hollo terbagi atas bagaian dari bertanggungjawab dengan ukuran prestasi manaje, pengunagnya kurangnya memadai. Kurangnya membandingkan pelaporan dikarenakan manajer divisi dan juga memiliki pimpinan kantor berpusat yang belum memiliki sepuas dari artinya kepentingan pada pelaporan bentuk bertujuan pendapatan yaitu Segment Performance Report. contohnya pimpinan kantor berpusat kedalam penilai prestasi dari divisi besi hollo bersagkutan pada laporan laba-rugi sesudah manajemen yang dapat dihasilkan dari divisi besi hollo kedalam satu dalam kurun waktu tersebut di lain pihak staf dan manajer dari divisi besi hollo tidak sepenuh mengerti isinya dari laporan yang dapat digunakan 
bagi sarana pengukuran prestasi manajer, misalnya tidak diterimanya gaji direksi maupun upah teknisi asing lain dari jasa pihak ketiga, ke dalam biaya yang tidak dapat dikendalikan oleh divisi. Di sisi lain telah mendapatkan penggunaan pelaporan prestasi manajer, tidak disadar oleh manajer divisi hal ini membawa dampak bagi manajer divisi besi hollo khususnya menyangkut dorongan kerja. Setuasi ini ditunjukan dengan fakta yang ada di bawah manajer dari divisi besi hollo merasa prestasinya diukur dengan membebankan biaya-biaya yang benar kecilnya biaya tesebut ditentukan oleh kantor berpusat. Supaya hal-hal tersebut di atas bisa diatasi maka secara keseluruhan laporan yang digunakan divisi perlu diadakan penyusuaian terhadap laporan prestasi. Hal ini secara tidak langsung sudah merupakan salah satu jalan keluar untuk mengatasi dampak dari berkurangnya motivasi dari manajer divisi. Di lain pihak penyesuaian-penyesuaian ini akan mempermudah pemakai laporan laba, hal ini manajer divisi maupun pimpinan kantor berpusat untuk pengambilan keputusan di bidang pengendalian. Kendala yang mungkin dihadapi sehubungan dengan penerapan laporan yaitu terbatasnya pengetahuan dari manajer divisi maupun pimpinan kantor pusat dalam hal penggunaan laporan prestasi, serta pakawai terdari dari manajer divisi dalam rangka penyajian laporan prestasi. Oleh sebab itu agar kendala-kendala biasa teratasi maka perlu diambil tindakan sebagai berikut:

1. Manajer divisi dan pimpinan kantor pusat perlu menggunakan jasa dari konsultan mengenai cara-cara penggunakan laporan prestasi.

2. Para staf dari manajer divisi perlu diadakan latihan dalam rangka pembuatan laporan prestasi khususnya menyangkut teknik pengklasifikasian biaya.

\subsection{Pembahasan}

\section{Laporan Prestasi Manajer Divisi Besi Hollo UD. Gading Jaya}

Tabel 2 adalah Laporan Prestasi Manajer Divisi Besi Hollo UD. Gading Jaya untuk periode 1 Januari 2017-3 Desember 2

\begin{tabular}{|c|c|c|c|}
\hline & Aktual & Anggaran & $\begin{array}{c}\text { Variansi } \\
\text { menguntungkan (tidak } \\
\text { menguntungkan) }\end{array}$ \\
\hline Penjualan & $\mathrm{Xxxx}$ & $\mathrm{Xxxx}$ & $\mathrm{XXXx}$ \\
\hline Dikurangi & & & \\
\hline Biaya variable & & & \\
\hline - biaya pabrik & Xxxx & $\mathrm{Xxxx}$ & $\operatorname{xxxx}$ \\
\hline - biaya & Xxxx & $\mathrm{Xxxx}$ & $\mathrm{XXXX}$ \\
\hline Penjualan \& Adm. Divisi & $\mathrm{Xxxx}$ & $\mathrm{Xxxx}$ & $\operatorname{xxxx}$ \\
\hline $\begin{array}{l}\text { Margin kontribusi } \\
\text { dikurangi : }\end{array}$ & $\mathrm{Xxxx}$ & $\mathrm{Xxxx}$ & $\operatorname{xxxx}$ \\
\hline Biaya Tetap Terkendali & & & \\
\hline - Biaya Pabrik & $\mathrm{Xxxx}$ & $\mathrm{Xxxx}$ & $\mathrm{XXXX}$ \\
\hline $\begin{array}{l}\text { - Biaya Penjualan dan Administrasi } \\
\text { Divisi }\end{array}$ & $\mathrm{Xxxx}$ & $\mathrm{Xxxx}$ & $\operatorname{xxxx}$ \\
\hline Total Biaya Variabel & $\mathrm{Xxxx}$ & $\mathrm{Xxxx}$ & XXXX \\
\hline $\begin{array}{l}\text { Kontribusi Divisi } \\
\text { dikurangi : }\end{array}$ & $\mathrm{Xxxx}$ & $\mathrm{Xxxx}$ & $\operatorname{xxxx}$ \\
\hline Biaya Tak Terkendali & $\mathrm{Xxxx}$ & $\mathrm{Xxxx}$ & $\mathrm{xxxx}$ \\
\hline Laba/rugi sebelum pajak & $\mathrm{Xxxx}$ & $\mathrm{Xxxx}$ & $\mathrm{XXXX}$ \\
\hline
\end{tabular}

Sumber : Data diolah Kota Manado 2017 
1. Penjualan. Penjualan dalam pos ini berupa semua penjualan produk dan penjualan lainlain dari divisi besi hollo.

2. Biaya Variabel. Yang ditunjukan dari biaya variabel di sini yaitu semua biaya yang bersifatnya variabel baik untuk pabrik maupun penjualan dan administrasi yang dikeluarkan sehubungan dengan pembuatan dan penjualan suatu produk dari divisi. Biaya variabel dalam divisi ini dapat dibagi menjadi dua bagian yaitu :

a. Biaya variabel pabrik. Biaya variabel pabrik dalam divisi ini terdiri atas: pemakaian bahan baku, upah langsung, dan biaya pabrik tak langsung (pemakaian bahan pembantu, biaya pemeliharaan mesin pabrik, pemakaian suplai pabrik, listrik, dan biaya pabrik lain).

b. Biaya variabel penjualan dan administrasi. Biaya-biaya yang termasuk dalam pos ini merupakan semua biaya penjualan dan administrasi yang sifatnya variabel bagi divisi besi hollo di mana biaya-biaya tersebut terdiri atas: biaya pemeliharaan kendaraan kantor, biaya pemeliharaan gedung kantor, listrik, air, biaya bunga bank, biaya administrasi bank, dan biaya telepon.

3. Margin Kontribusi. Dalam margin kontribusi yang dapat dimaksudkan dari pendapatan dan penjualan pada bagaian biaya variabel tetap bagi divisi besi hollo.

4. Biaya Tetap Terkendali. Yang dapat dimaksudkan dengan biaya dapat terkendali dan biaya tidak dapat terkendali adalah biaya-biaya yang diberikan oleh divisi besi hollo dan dapat dikendalikan oleh manajer divisi besi hollo . Dalam biaya tetap terkendali terdapat dua unsur yaitu: biaya tetap pabrik (upah tak langsung, listrik, air), dan biaya tetap penjualaan dan administrasi pada biaya tetap penjualan dan administrasi dari divisi besi hollo terdiri atas: Gaji karyawan kantor, Biaya pemeliharaan kendaraan kantor, Listrik, Air, dan Biaya operasi lain.

5. Kontribusi Divisi. Kontribusi divisi yaitu pemberian diri kepada divisi yang bersangkutan kepada divisi yang didapatkan melalui saran atau menjual barang dengan biaya-biaya variabel serta biaya tetap yang dapat digunakan oleh manajer divisi.

6. Biaya Tak Terkendali. Yang ditunjukan dengan biaya tak terkendali bagi divisi merupakan semua biaya yang diberikan dari divisi di mana pengukuran itu tidak dapat dipengaruhi oleh keputusan manajer divisi besi hollo. Biaya-biaya tak terkendali itu terdiri atas : Upah tak langsung, Upah ini yaitu upah dari teknis asing, Gaji direksi, Jasa pihak ketiga, Biaya penyusutan aktiva tetap, dan Biaya sewa gedung.

7. Laba/(Rugi) sebelum pajak. Laba/(Rugi) sebelum pajak yaitu selisih antara penjualan dan biaya-biaya yang sifatnya terkendali maupun tak terkendali bagi divisi besi hollo sebelum dikurangi taksiran pajak.

\section{KESIMPULAN DAN SARAN}

\subsection{Kesimpulan}

Hasil penelitian ini yang dapat melakukan penilaian terhadap Segment Performance Report sebagai alat penilaian prestasi manajer pusat biaya pada UD. Gading Jaya dapat disimpulkan sebagai berikut:

1. Laporan prestasi yang dihasilkan oleh manajer divisi telah mencangkup beberapa hal sebagai berikut:

a. Sebagai sarana pertanggungjawaban dari manajer divisi atas wewenang yang dilimpahkan, dalam hal ini aktivitas organisasi secara keseluruhan.

b. Laporan dari manajer divisi digunakan oleh pimpinan kantor pusat sebagai sarana penilaian prestasi manajer divisi.

c. Laporan ini berisikan pendapatan dan biaya yang dapat bisa dilakukan maupun sebagian dari biaya yang tidak dapat diklakuan oleh manajer divisi. 
2. Konsep dalam Segment Performance Report salin mencangkup hal-hal yang telah disebutkan pada poin satu di atas, juga harus mencakup hal-hal sebagai berikut:

a. Isi laporan harus dipindahkan ke biaya-biaya yang bersifat variabel, biaya yang bersifat tetap yang terdapat dikendalikan dan biaya yang bersifat tak terkendali bagi manajer divisi.

b. Laporan harus dibentuk kontribusi yang menunjukkan kontribusi atas biaya-biaya variabel, kontribusi atas biaya-biaya tetap yang bisa dilakukan divisi maupun kontribusi dari biaya-biaya yang tidak bisa dilakukan divisi yang bersangkutan.

c. Laporan harus disertai dengan anggaran serta selisih (varians) antara laporan yang aktual dengan yang anggaran. Hal-hal yang disebutkan terakhir belum tercakup di dalam laporan prestasi manajer divisi.

3. Dengan tidak terdapatnya elemen-elemen dari Segment Performance Report didalam laporan prestasi manajer divisi yang seperti yang diperlihatkan dalam poin dua di atas, menyebabkan laporan prestasi manajer divisi belum efektif untuk digunakan sebagai alat penilaian prestasi.

4. Belum memadainya laporan prestasi manajer divisi untuk digunakan sebagai alat penilaian prestasi disebabkan karena terbatasnya pengetahuan dari manajer divisi maupun pimpinan kantor pusat serta pengetahuan dari staf manajer divisi dalam rangka penyajian laporan prestasi.

\subsection{Saran}

Penilaian prestasi yang memadai ditentukan oleh efektifnya laporan prestasi yang digunakan untuk tujuan tersebut. Kenyataan yang ada mengenai laporan prestasi divisi seperti yang diuraikan pada kesimpulan di atas, menunjukkan efektifitas laporan sebagai alat penilaian prestasi belum terpenuhi. Dikatakan demikian karena saran-saran tersebut akan mendatangkan manfaat berupa:

a. Akan mendorong motivasi kerja manajer divisi karena prestasinya diukur berdasarkan kontribusi pada biaya yang dapat dikendalikan dari manajemen divisi yang bersangkutan.

b. Berdasarkan laporan prestasi akan mempermudah pimpinan kantor pusat untuk mengambil keputusan dalam hal pengendalian.

Menyadari kekurangan dan kelemahan yang ada tentunya penulisan ini belum sempurna untuk mengatasi permasalahan yang dihadapi. Karena itu dengan menggunakan tentu jasa dari konsultan mengenai tata cara penyusunan dan penggunaan laporan prestasi akan dapat lebih menyempurnakan permasalahan di samping mengambarkan metodologi atau pun halhal yang berkaitan dengan masalah di atas.

\section{DAFTAR PUSTAKA}

Ahmad, Kamarudin. 2013. Akuntansi Manajemen : Dasar - Dasar Konsep Biaya dan Pengambilan Keputusan. Cetakan ke-8. PT. Raja Grafindo Persada. Jakarta.

Adepju O.O. Opafunzo Z. O Lawal A.F.2017. Influence Of Pefpormance A ppraisal On Quality Of Service Delivery: A Case Of Primary Health Care Facilities, Southwestrn Nigeia

Andre Wira Nugraha. “ Penilaian Kinerja Manajer Pusat Pendapatan, Pusat Biaya, dan Pusat Laba Pada PT. Popok Kalimantan Timur".

Antohony, N, Rbert. D, Jhon, 2013. Sistem Pengendalian Manajemen, Edisi Kesembilan. Penerbita Erlangga Jakarta.

"Akuntansi Manajemen: Informasi Biaya untuk Mengendalikan Aktivitas Operasi \& Investasi”. Cetakan ke dua. Kencana, Jakarta.

Badriyah, hurriaya. 2015. Buku Pintar Akuntansi Dengan Untuk Orang Awam. Penerbitan Andi Yongjakarta. 
Choundary G. B and Puranik. 2014. Study on employee performance appraisal in health care

Copeland, R. D. P, 2011, Akuntansi Manajemen. Penerbit PT. Rajagravindo Persada, Jakarta.

Desasler 2015 “Performance Appraisal is evaluating an employee's current past performance relative to his or her performance

Halim, Dkk2013 .Sistem Pengendalian Manajemen, Edisi Ketiga,Sekolah tinggi ilmu manajemen YPKPN, Yongyakarta.

Ishak \& Arief Sugiono 2015. Akuntansi,Informasi dalam pengambilan keputusan.Jakarta: PT.Grasindo.

Julita Tangkudung, 2016. “Segment Performance Report Sebagai Alat Penilaian Presentasi Manajer ( Studi Kasus PT. Ropica Cocoprima)".

Jessica Claudia Hehi, 2013. "Segment Performance Report Sebagai Alat Penilaian prestasi manajer pada PT. Tropica Cocoprima Skripsi, Universitas Sam Ratulangi Manado.

Mathis dan Jekson 2014:82, penilaian kinerja (performance apprais) 